УДК 378.004.09.

DOI: 10.37026/2520-6427-2019-100-4-74-79

\section{Андрій ЯЦИШин,}

доктор технічних наук, стариий науковий співробітник, провідний науковий співробітник Інституту інформаційних технологій i засобів навчання НАПН Украӥни, м. Київ

\section{Свген РОМАНЕНКО,}

доктор наук із державного управління, професор, проректор Міжрегіональної академії управління персоналом, м. Київ

Ірина ДЕЙНЕГА,

кандидат історичних наук, дочент, директор Навчально-наукового інституту неперервної освіти

Начіонального авіачійного університету, м. Київ

\author{
Анна ЯЦИШИН, \\ кандидат педагогічних наук \\ стариий науковий співробітник, \\ заступник директора з наукової роботи \\ Інституту інформаційних технологій \\ і засобів навчання НАПН України, м. Київ
}

Валерія КОВАЧ, кандидат технічних наук, заступник директора Навчально-наукового інституту неперервної освіти Національного авіаційного університету, м. Київ

\title{
ХМАРНІ ТЕХНОЛОГІЇ ТА ПЕРСПЕКТИВИ ЇХ ВИКОРИСТАННЯ В ПІДГОТОВЦІ МАЙБУТНІХ ДОКТОРІВ ФІЛОСОФІї
}

Нині в Україні важливим є питання гармонізаиії з європейськими та світовими науковими ініціативами, зокрема щуодо застосування хмарних технологій $i$ сервісів у підготовиі фахівиів різних спеціальностей. Потреба модернізачії підготовки майбутніх докторів філософії (PhD) зумовлена передусім викликами нового інформачійного й глобалізованого суспільства та ичифровою трансформацією всіх сфер життя, серед яких - освіта та наука. Проведене дослідження спрямоване на визначення перспективних напрямів застосування хмарних сервісів у підготовиі майбутніх PhD. Розглянуто досвід застосування хмарних технологій та їх сервісів в освітньо-науковому просторі у праиях украӥнських та зарубіжних учених. Здійснено аналіз вітчизняного досвіду щодо підготовки майбутніх фахівців різних спеціальностей, зокрема і майбутніх PhD із застосуванням хмарних сервісів. Наголошено, шьо вдосконалення підходів до підготовки майбутніх $\mathrm{PhD}$ на основі застосування хмарних сервісів дозволить підвищчити в них рівень розвитку иифрової компетентності, а використання хмарних сервісів для підтримки наукової та науково-організаційної діяльності сприятиме підвищенню рівня організаиії та здійсненню наукових досліджень.

Ключові слова: хмарні технології, хмарні сервіси, аспіранти, майбутні доктори філософії, PhD, ичифровізація освіти, IKT.

Сегодня в Украине важным является вопрос гармонизации с европейскими и мировыми научными инициативами, в частности по применению облачных технологий и сервисов в подготовке специалистов различных специиальностей. Потребность модернизачии подготовки будущих $\mathrm{PhD}$ обусловлена прежде всего вызовами нового информаичонного и глобализироваванного общества, а также циифровой трансформачией всех сфер жизни, среди которых - образование и наука. Проведенное исследование направлено на определение перспективных направлений применения облачных сервисов в подготовке 
будущих PhD. Рассмотрен опьт применения облачных технологий и их сервисов в образовательно-научном пространстве в трудах украинских и зарубежнblх ученых. Осуществлен анализ отечественного опьтта подготовки будущих спещиалистов различных специальностей, в том числе и будущих PhD с применением облачных сервисов. Отмечено, что совершенствование подходов к подготовке будущих PhD на основе применения облачных сервисов позволит повысить в них уровень развития ичирровой компетентности, а использование облачных сервисов для поддержки научной и научно-организащионной деятельности будет способствовать повышению уровня организации и осуществлению научных исследований.

Ключевые слова: облачные технологии, облачные сервисы, аспиранты, $P h D$, цүифровизация образования, ИКТ.

Currently, it is important in Ukraine to harmonize cloud technologies application with European and world scientific initiatives. Need to modernize preparation of future PhDs is caused by challenges of new information, globalized society and digital transformation of all spheres of life, including education and science. The research was aimed to determine features of cloud services application in preparation of future PhDs. Experience of cloud technologies and their services application in educational and scientific space in researches of foreign and Ukrainian students was considered. Ukrainian experience in preparation of future PhD of various specialties with cloud services application was analyzed. It was emphasized that approaches improving to preparation of future PhDs based on cloud services application would increase their level of digital competence. It is recommended to include a separate course or module of specific discipline on work with cloud technologies and services during preparation of future PhDs. It is important to improve disciplines and tools content to support education process. It can be learning of disciplines using cloud technologies or services by future PhD's. Also, cloud services application to support scientific and scientific-organizational activities will increase level of organization and implementation of scientific research. It is important to create cloud-oriented environment for preparation of future PhDs in higher education and research institutions. Creation of a cloud-oriented educational and scientific environment should be based on the principles of open education. Authors recommend using cloud-based platforms and services (Microsoft Office 365; Google Apps for Education; SageMathCloud, Amazon Web Services, Microsoft Azure, Xen, WMWare or other), messengers (Telegram or other).

Key words: cloud technologies, cloud services, graduate students, PhDs, digitalization of education, ICT.

Постановка проблеми. Концепцією розвитку цифрової економіки та суспільства України на 2018-2020 роки визначено, що проблеми цифрової трансформації суспільства, сьогодні в Україні є першочерговими. У зв'язку з цим важливою $є$ участь учених та IT-компаній у проєктах СC із проведення довгострокових досліджень, що в майбутньому стануть джерелом інновацій у таких сегментах, як: майбутні перспективні технології; майбутні мережі; майбутні інтернет-дослідження та експерименти та ін. Головним завданням при цьому є створення експериментальної бази для проведення досліджень та тестування квантових технологій на розподілених грід- і хмарних інфраструктурах. Для забезпечення ефективної участі України у європейському дослідницькому та інноваційному просторі важливим $є$ розвиток власної наукової цифрової інфраструктури відповідно до пріоритетних напрямів, в яких очікується високотехнологічне зростання або прорив. Підключення українських наукових цифрових інфраструктур до європейської хмари відкритої науки та європейської інфраструктури даних дасть поштовх до вирішення актуальних українських наукових завдань iз мінімальним використанням державних ресурсів. Для часткового вирішення окреслених вище питань $\mathrm{i}$ проводяться наукові дослідження, що виконуються у закладах вищої освіти та наукових установах майбутніми докторами філософії (далi $-P h D)$. Оволодіння сучасними досягненнями в розвитку виробничих та інформаційних технологій зумовлює нові завдання щодо підготовки аспірантів, модернізації структури освітньо-кваліфікаційних рівнів, оновлення вимог до третього ступеня - доктора філософії. Подальші пошуки ефективних підходів до підготовки аспірантів, спрямовані на досягнення наукою та освітою сучасних світових рівнів та зростання інтелектуального потенціалу держави $є$ актуальними [7].

Формування високотехнологічного середовища навчання на основі хмарних технологій, як зауважує М. П. Шишкіна [11], сприятиме об'єднанню освітніх ресурсів навчального призначення та підтримці наукових досліджень, охопленню різних рівнів навчання, підготовці фахівців та кадрів вищої кваліфікації, сприятиме вирішенню освітніх проблем, подоланню розриву між процесом наукового пошуку, наприклад, педагогічного, і рівнем упровадження та використання його результатів. Крім того, дослідниця наголошує, що саме хмарні технології якнайкраще відповідають потребам вирішення нагальних соціальних та освітньо-культурних проблем суспільства, основні серед яких - підвищення рівня доступності та якості освіти, взаємозв'язок процесів наукових досліджень та підготовки науково-педагогічних кадрів, удосконалення проектування, формування та забезпечення функціонування освітньо-наукового середовища закладів освіти. Хмарні технології постають інструментом реалізації принципів людиноцентризму, рівного доступу до результатів наукових досліджень та навчальних матеріалів [10]. Зважаючи на це, актуальним та важливим $є$ навчання аспірантів застосовувати хмарні технології для виконання наукових досліджень, а сам процес підготовки аспірантів потребує активного застосування хмарних сервісів.

Аналіз наукових досліджень i публікацій. Вітчизняні та зарубіжні вчені (В. Ю. Биков [1], Т. А. Вакалюк [2], О. Г. Кузьмінська, Н. В. Морзе [4], Ю. Г. Носенко [9], М. В. Попель [5], С. О. Семеріков [2], М. П. Шишкіна [11], Guolei Zhang, Jia Li, Li Hao [13], U. Singh, P. K. Baheti [16] та ін.) у своїх дослідженнях наголошують на важливості застосування інформаційно-комунікаційних технологій (далі - IКТ), зокрема хмарних технологій і сервісів, для вищої освіти. Різні аспекти підготовки аспірантів розглядали: Н. В. Базелюк, І. Ю. Регейло, С. О. Сисоєва, Ж. В. Таланова, Я. В. Топольник, T. I. Коваль та ін. Певний досвід підготовки аспірантів і докторантів проаналізовано та описано О. М. Спіріним, Ю. Г. Носенко, А. В. Яцишин [8; 9; 12]. 
Оскільки інформаційні технології постійно вдосконалюються, виникає потреба подальшого дослідження різних аспектів застосування хмарних технологій i сервісів у підготовці майбутніх докторів філософії.

Мета статті - дослідити перспективні напрями застосування хмарних технологій у підготовці майбутніх докторів філософії.

Виклад основного матеріалу. Світові компанії і державні інституції інвестують у перспективні цифрові технології, серед яких - мобільні засоби комунікації, мережні соціальні медіа, системи аналізу «великих даних», «інтелектуальні» пристрої, що керують підключеними до них об'єктами і датчиками та ін. Серед них ключову роль відіграють хмарні технології, які використовуються по всьому світу. Хмарні обчислення визнано пріоритетним напрямом технологічного розвитку, про що свідчить низка міжнародних документів (Європейська стратегія хмарних обчислень, Федеральна урядова ініціатива хмарних обчислень у США) та урядових ініціатив різних країн, згідно з якими розпочато масштабні освітні проекти у США, країнах Свросоюзу, Японії та ін., проводяться численні міжнародні конференцій та публікуються наукові праці. Зважаючи на це, проблеми проектування сервісів і технологій хмарних обчислень для використання у навчальному процесі закладів освіти належать до першочергових у сфері інформатизації [16].

Коротко розглянемо основні поняття, що функціонально пов'язані між собою: «хмарні технології», «хмарні технології навчання», «хмарні сервіси», «хмаро орієнтоване середовище». Національним інститутом стандартів США (The NIST Definition of Cloud Computing) було визначено поняття «хмарні обчислення» (Cloud Computing), під яким варто розуміти модель зручного мережного доступу до загального фонду обчислювальних ресурсів (наприклад, мереж, серверів, файлів даних, програмного забезпечення та послуг), які можуть бути швидко надані за умови мінімальних управлінських зусиль та взаємодії із постачальником. Крім того, цим Інститутом було розроблено рекомендації, в яких запропоновано п'ять базових характеристик хмарних обчислень, завдяки яким можна відрізнити означені системи від інших різновидів IКТ. До цих характеристик відносять: вільний (повсюдний) мережний доступ; самообслуговування за потребою; об'єднання ресурсів у пул (незалежність від місцезнаходження ресурсу); вимірюваність сервісу (оплата після надання послуг); швидка еластичність (надання і вивільнення ресурсу в потрібній кількості та в будь-який час [16]. У [2] вказано, що хмарні технології регулюються чотирма моделями розгортання (публічною, гібридною, приватною та хмарою співтовариства). У звітних матеріалах компанії Gartner хмарні технології були названі «черговим суперконцептом серед IКТ, на який покладено надзвичайні сподівання».

В. Ю. Биков визначає концепцію хмарних технологій через поняття «віртуальний мережний майданчик». Завдяки спеціальному інтерфейсу користувача, що підтримується системними програмними засобами мережного налаштування, в адаптивних інформаційно-комунікаційних мережах формуються мережні віртуальні ІКТ-об'єкти. Означені об'єкти - це мережні віртуальні майданчики, що виступають у ролі ситуаційної складової логічної мережної інфраструктури інформаційно-комунікаційних мережах із тимчасовою відкритою гнучкою архітектурою, що за своєю будовою і часом існування відповідає персоніфікованим потребам (як індивідуальним, так і груповим) користувача, а їхнє формування і використання підтримується хмаро орієнтованими технологіями» [1].

У документі [15] поняття «хмарні сервіси» визначено «як сервіси, які забезпечують користувачеві мережний доступ до масштабованого і гнучко організованого пулу розподілених фізичних або віртуальних ресурсів, що постачаються в режимі самообслуговування й адміністрування за зверненням (програмне забезпечення, простір для зберігання даних, обчислювальні потужності тощо)».

М. П. Шишкіна [11] під «хмаро орієнтованим середовищем закладу вищої освіти» визначає створене у цьому закладі середовище діяльності учасників освітнього і наукового процесу, в якому для реалізації комп'ютерно процесуальних функцій цілеспрямовано розроблена віртуалізована комп'ютерно-технологічна інфраструктура. При цьому хмарні сервіси важливо застосовувати для того, щоб зробити доступним користувачеві електронні освітні ресурси, що складають змістовне наповнення хмаро орієнтованого середовища.

У дисертації [11] проаналізовано досвід застосування хмарних технологій у низці закордонних закладів вищої освіти, а саме: Каліфорнійському університеті в Берклі (Amazon Web Service); Массачусетському технологічному інституту (математичні пакети програм: Mathlab, Mathematica, Maxima, Maple, R); університеті Hochschule Furtwangen University (розгорнута корпоративна хмаро орієнтована інфраструктура «Cloud Infrastructure and Application») та ін. Також зарубіжний досвід застосування хмарних технологій і сервісів для потреб вищої освіти описано в колективних роботах (Guolei Zhang, Jia Li, Li Hao [1]; U. Singh , P. K. Baheti) [16].

У європейському освітньому просторі відпрацьовано певний підхід до розвитку науково-дослідницьких мереж та інфраструктур, зокрема створення Європейського форуму зі стратегій щодо науково-дослідницьких інфраструктур; Свропейською комісією у 2013 р. оприлюднено концептуальний документ «Цифрова наука», в якому окреслено основні засади бачення проблем розвитку наукових досліджень, удосконалення цифрових технологій (хмарних технологій), а також інтеграції у програму Горизонт 2020. Таким чином, наука має стати більш глобальною, більш творчою і ближчою до суспільства [11].

Досвід українських закладів вищої освіти (далі - 3ВО) щодо застосування хмарних технологій і сервісів представлено в низці досліджень. Так, у [5] обгрунтовано доцільність та експериментально підтверджено ефективність застосування хмарного сервісу SageMathCloud у навчанні математичних дисциплін; [2] описано теоретико-експериментальне дослідження проблеми проектування і використання хмаро орієнтованого навчального середовища у підготовці бакалаврів інформатики; [11] окреслено формування і розвиток хмаро орієнтованого освітньо-наукового середовища закладу вищої освіти; [7] представлено досвід Житомирського державного технологічного університету та практика використання Google Drive та Telegram для підготовки майбутніх фахівців із механічної інженерії; [6] охарактеризовано методику використання мобільних математичних середовищ (і хмарних сервісів) у процесі навчання вищої математики студентів економічних спеціальностей та ін. 
У Концепції розвитку цифрової економіки та суспільства України на 2018-2020 роки передбачено здійснення заходів щодо впровадження відповідних стимулів для цифровізації економіки, суспільної та соціальної сфер, усвідомлення наявних викликів та інструментів розвитку цифрових інфраструктур, набуття громадянами цифрових компетенцій, визначено критичні сфери та проекти цифровізації, стимулювання внутрішнього ринку виробництва, використання та споживання цифрових технологій, зазначено, що інтеграція української науки у європейський дослідницький простір забезпечить можливість розвитку передових наукових ідей, участь у міждисциплінарних проектах, що зосереджуються на перспективних ідеях, технологіях та інноваціях. При цьому одним із важливих завдань $є$ формування грунтовної національної політики цифровізації освіти як пріоритетної складової реформи освіти, а одним із ключових елементів Сдиного цифрового ринку Свропи та складовою парадигми «Відкриті інновації - Відкрита наука - Відкритість до світу», яка розвивається в рамках європейського дослідницького та інноваційного простору, є розбудова європейської хмари відкритої науки та європейської інфраструктури даних. Реалізація основних постулатів описаної вище Концепції вже відбувається впродовж певного часу, зокрема в Україні виконуються різні наукові дослідження в цьому напрямі.

Обгрунтуємо переваги застосування хмарних технологій і сервісів для підготовки майбутніх $\mathrm{PhD}$.

У дослідженні [11] вказано, що із розвитком хмарних технологій існує значна потреба у перегляді підходів до розроблення і постачання ІКТ-послуг в аспекті їх інтеграції, що також торкається і питання методик навчання інформатичних дисциплін. Застосування хмаро орієнтованих ресурсів і інформаційно-комунікаційних платформ у викладанні різноманітних дисциплін у сфері вищої освіти стає нагальною потребою модернізації педагогічних методик і технологій, адже це свідчить про перехід до нових моделей організації навчальної і професійної діяльності, що грунтується на розподіленому використанні електронних ресурсів і обчислювальних потужностей. Передусім важливим $\epsilon$ застосуванням гібридних сервісних моделей та інфраструктурних рішень, що поєднують різні загальнодоступні та корпоративні сервіси на базі єдиної платформи [11]. У навчальному процесі знаходять своє місце хмаро орієнтовані додатки і сервіси, наприклад, Microsoft Office 365, Google Apps та ін. Ці засоби містять набір «офісних» функцій, які можна застосовувати для підтримування різних типів навчальної та навчально-дослідницької діяльності: корпоративна електронна пошта і календар для планування й організації заходів; засоби опрацювання в режимі онлайн офісних додатків (Word, Excel, Power Point та ін.), що уможливлює як колективну, так і індивідуальну роботу з певними навчальними матеріалами, що містяться в хмарному сховищі (One Drive, Google Drive); створення груп для організації спільного доступу до документів та їх колекцій; електронний записник (One Note), в якому можна розміщувати записи як для індивідуального, так і колективного використання; вебконференція (Skype або інша), засобами якої можна організовувати відеоконференцзв'язок, голосовий зв'язок або чат з учасниками чи групою тощо. Існує також широкий спектр хмарних сервісів, серед яких: онлайн-фото і відеоредактори, засоби опрацювання вебсторінок, сервіси перекладу, перевірки орфографії, наявності запозичень у тексті та багато інших [11].

Розгортання у 3ВО та наукових установах хмаро орієнтованого освітньо-наукового середовища - суттєва передумова підготовки ІКТ-компетентних фахівців, здатних до подальшого активного, доцільного, науково обгрунтованого застосування хмарних технологій у власній професійній діяльності. Для ефективності запровадження хмарних сервісів, важливим $є$ проведення спеціального навчання, запровадивши відповідні його елементи, передусім для підготовки, перепідготовки, підвищення кваліфікації наукових і науково-педагогічних кадрів, аспірантів і магістрів [10].

Хмарні сервіси доцільно застосовувати для підтримування практичних занять 3 IT-навчання та розгортання хмаро орієнтованих комп'ютерних лабораторій для різних типів IT-курсів. Діяльгість навчальних лабораторій з IT особливо зручно проводити за підтримки засобів хмарних технологій, урахуванням надшвидких типів розвитку IT-індустрії. Тобто, це гнучкий і динамічний інструмент для налаштування середовища відповідно до навчальних потреб [11].

Відомі виробники ІТ-послуг пропонують для освітніх цілей певні хмарні сервіси: 1) Blue Cloud від IBM - засоби для підтримування міграції даних із традиційної IT-інфраструктури у хмарну під назвою IBM Cloud Academy (IBM, 2009); 2) App Engine від Google - програму Google Apps for Education program (Google, 2010) для підтримування закладів освіти; 3) Microsoft Windows Azure - хмарні рішення для закладів освіти (Microsoft, 2011). Можуть бути використані всі види сервісів - IaaS, PaaS i SaaS [11].

Зауважимо також, що окремий напрям досліджень присвячений застосуванню хмарних технологій щодо підтримки спільної роботи колективу програмістів над розробленням коду. Цей напрям отримав назву «віртуальні комп'ютерні лабораторії» - virtual computing laboratories (VCL). Під віртуальною комп'ютерною лабораторією в даному випадку автори розуміють технологію, яка може бути використана з метою розгортання розподілених невеликих дата-центрів та IT-сервісів для закладів освіти (зазвичай вони застосовуються для формування на їх основі навчальних IT-лабораторій). Нині з'являються хмарні версії відомих виробників постачальників сервісів, зокрема Sage MathCloud, Maple, MATLAB, Maple Net, MATLAB web-server, WebMathematica, Calculation Laboratory та ін. [11].

Застосування хмарних обчислень дають змогу розгорнути знаряддя, які за потреби можна масштабувати для обслуговування довільної кількості користувачів. Досить часто користувачі використовують хмари (хмарні сервіси), навіть не підозрюючи про це [4].

На сьогодні важливим $є$ поліпшення навчального і наукового співробітництва завдяки спільному доступу до електронних ресурсів і відкритих інформаційних систем: бібліотечних, журнальних, систем відеоонференцій тощо. Хмаро орієнтовані електронні дослідницькі інфраструктури реалізуються завдяки використанню хмарних сервісів відповідних ІКТ-платформ. Під хмаро орієнтованими корпоративними інформаційними системами варто розуміти такі, що надають засоби для підтримки освітньої діяльності та наукових досліджень (обчислювальні потужності, простір для зберігання даних або мережеві ресурси для організації взаємозв'язків тощо) та реалізуються на базі хмарних сервісів [11]. 
Здійснивши аналіз робіт [2; 5; 10; 11], нами було виокремлено перспективи створення хмаро орієнтованого освітнього середовища: зняття обмежень щодо доступу до навчальних матеріалів із будь-якого пристрою, в будь-якому місці та в будь-який час; розвиток персоніфікованих навчальних середовищ; розвиток сервісно-орієнтованого підходу, збільшення кількості SaaS; удосконалення сервісів колективної роботи (відеоконференцзв'язку, доступу до спільного контенту); запровадження уніфікованої ІКТ-інфраструктури закладу освіти, зростання використання IaaS; розвиток гібридних сервісних моделей; використання як корпоративних, так і загальнодоступних ресурсів, інтеграція сервісів; зростання вимог до сумісності, надійності, безпеки та ін.; поширення підходу «великих даних» у ході проектуванні педагогічних IКТ-систем; скорочення фінансових витрат на ліцензування і підтримування сервісів.

Хмарні технології та сервіси спрямовані на підтримування різних типів діяльності науково-педагогічних працівників у віртуальному середовищі. Це пов'язано iз формуванням груп, спільнот, які навчаються і віртуально взаємодіють у режимі реального часу. Щоб організовувати діяльність у таких спільнотах, використовуються функції, що забезпечують колективний доступ до навчального контенту для групи користувачів, можливість для викладача проглядати всі комп'ютери в групі, концентрувати увагу студентів завдяки повідомленням, підключати або відключати учасників навчального процесу, поширювати файли або посилання серед учасників цільової групи, надсилати повідомлення конкретним студентам. Для навчання та організації діяльності у віртуальному класі можуть бути використані також хмарні платформи і сервіси (Wiziq, OpenClass, VideoWhisper та ін.). Крім того, виникають віртуальні класи (Whiteboard, Breakout rooms), системи спільної роботи з додатками у хмаро орієнтованому середовищі, інтернет-конференції (вебтури, вебінари), онлай- платформи для дистанційного навчання (Google Open Class, Canvas); додатки GoogleAPs для освітніх закладів (Gmail, Календар, Blogger, Групи, Карти, Reader, YouTube, Talk) та ін. [16].

У роботі [10] рекомендовано застосовувати хмарні сервіси Google. Серед основних переваг таких сервісів, зокрема для вищої освіти, варто виокремити такі: безкоштовність; надійність (надійне збереження даних, захищеність від збоїв та ін.); відсутність необхідності розгортати «хмару»; інтуїтивно зрозумілий інтерфейс, простота у використанні; наявність універсального облікового запису, що забезпечує доступ до всіх сервісів та широкого функціоналу, що постійно оновлюється і здатний забезпечити підтримку практично всіх видів діяльності установи; доступність із будь-якого цифрового пристрою, підключеного до мережі Інтернет («будь-де», «будь-коли»); можливість використання на різних платформах (Windows, Android, iOS та ін.).

У публікації [13] окреслено проблеми, вирішення яких можливо із застосуванням хмарних сервісів Google (Gmail, Google-пошук, Google Документи, Презентації, Таблиці, Google Календар, Google Диск, Google Академія, Google Книги, Hangouts, Google Форми, Google Keep, Google Sites, Google+, Blogger), які доцільно використовувати для проведення дослідження та в як засіб підтримки процесу підготовки аспірантів: добір джерельної бази дослідження (зарубіжна та вітчизняна література); оформлення та підготовка рукопису дисертаційної роботи чи наукової статті; проведення онлайн-опитувань; організація та управління процесом підготовки аспірантів і докторантів.

А. В. Соловйов у своїй публікації [7] описує практику використання хмарних сервісів Google Drive та Telegram 3 метою підготовки майбутніх фахівців із механічної інженерії. Швидкий доступ до необхідної інформації загалом та взаємодія між викладачем та студентом за допомогою Google Drive та Telegram зокрема дозволяє зробити навчальний процес набагато результативнішим. Так звані «боти» можуть бути створені окремо для кожної із наявних навчальних дисциплін. У Telegram за допомогою розділу «Saved Massages», що призначений для збереження й архівування окремих повідомлень та записів, викладач може заздалегідь завантажити завдання, інформаційні матеріали та ін., щоб допомогти студентам у пошуку потрібної практичної роботи. Можна забезпечити певне спрощення процесу отримання завдань із метою виконання лабораторних чи самостійних робіт. За допомогою повного переліку завдань, доступного у створеному Telegram-боті, студент може вільно орієнтуватися у визначених на поточний семестр завданнях, самостійно переходити до виконання наступних робіт [7].

Наголошуємо, що підготовка майбутніх $\mathrm{PhD}$ має відбуватися із застосуванням хмарних технологій та їх сервісів. В Інституті інформаційних технологій i засобів навчання НАПН України (далі - IIТЗН НАПН України) у підготовці аспірантів хмарні технології і сервіси активно застосовувалися ще до 2015 р., а із 2016 р. у закладі функціонує освітньо-наукова програма підготовки докторів філософії за спеціальністю 011 «Науки про освіту», зокрема спеціалізація «Інформаційно-комунікаційні технології в освіті» передбачає обов'язкові дисципліни та дисципліни за вибором аспіранта. До навчального плану підготовки майбутніх $\mathrm{PhD}$ було введено окрему дисципліну «Хмаро орієнтовані технології підтримки науковоосвітньої діяльності», а в інших дисциплінах є певні модулі та теми, що також передбачають застосування хмарних сервісів і подальшу роботу 3 ними. Крім того, в ІІТЗН НАПН України створено хмаро орієнтоване середовище для підготовки майбутніх $\mathrm{PhD}$, зокрема розгорнуто «хмару» із застосування Office 365, активно застосовуються SageMathCloud та хмарні сервіси Google.

ІІТЗН НАПН України плідно співпрацює 3 низкою ЗВО України, зокрема створено спільні науково-дослідні лабораторії та укладено угоди про співпрацю, завдяки яким майбутні $\mathrm{PhD}$ можуть виконувати власні експериментальні дослідження на базі 3ВО та проходити викладацьку практику, організовувати і проводити спільні заходи (конференції, семінари тощо). Так, щорічно проводиться Міжнародний науково-методичний інтернет-семінар «Хмарні технології в освіті», за результатами якого видається збірник статей англійською мовою. Варто також відзначити співпрацю ІІТЗН НАПН України із Національним авіаційним університетом (далі - НАУ), оскільки на базі Навчально-наукового інституту неперервної освіти розпочато підготовку магістрів за спеціалізацією «Інформаційні технології в освіті». До речі, в НАУ для підвищення ефективності підготовки магістрів та підготовки PhD планують активніше застосовувати хмарні технології та хмарні сервіси. 
Висновок. Потреба модернізації підготовки майбутніх $\mathrm{PhD}$ зумовлена викликами нового інформаційного, глобалізованого суспільства та цифровою трансформацією усіх сфер життя, зокрема освіти та науки. Отже, до перспектив використання хмарних технологій у підготовці майбутніх $\mathrm{PhD}$, варто віднести:

1) розширення доступу користувачів до кращих зразків електронних освітніх ресурсів і сервісів, розвиток особистості, потенційне отримання максимально можливих результатів застосування IКТ для досягнення цілей навчання;

2) розгортання хмаро орієнтованого навчально-наукового середовища сприятиме: мобільності студентів та викладачів, рівному доступу до освітніх систем, наданню якісної освіти, формуванню структури та реалізації освітніх послуг; таке навчальне середовище має відповідати певним характеристикам, як-от: доступність та мобільність, відкритість, цілісність та безперервність вищої освіти, систематичність, послідовність та структурованість, інноваційність, інтеграція iз хмаро орієнтованими ресурсами, наочність, функціональність, колективність, забезпечення проектної діяльності, науковість, надійність, підтримування процесів комунікації, гнучкість та адаптивність, індивідуалізація, повнота інформаційних ресурсів, зручність;

3) удосконалення підготовки майбутніх $\mathrm{PhD}$ на основі застосування хмарних сервісів, дозволить підвищити у них рівень розвитку цифрової компетентності;

4) уведення окремої навчальної дисципліни (модулів до певних дисциплін) щодо безпосередньої роботи із хмарними технологіями та сервісами чи оновлення засобів під час викладання дисциплін;

5) застосування хмаро орієнтованих платформ і сервісів (Google Apps for Education, Microsoft Office 365, SageMathCloud, Amazon Web Services, Microsoft Azure, Xen, WMWare тощо), сервісів для створення комунікації та підтримки зворотного зв'язку (соціальні мережі й месенджери Telegram та ін.).

Подальшого дослідження потребують практичні аспекти застосування хмарних сервісів та електронних систем відкритого доступу у навчанні різних дисциплін майбутніх $\mathrm{PhD}$.

\section{СПИСОК ВИКОРИСТАНОЇ ЛІТЕРАТУРИ}

1. Биков В. Ю. Технології хмарних обчислень, ІКТ-аутсорсінг та нові функції ІКТпідрозділів навчальних закладів і наукових установ / В. Ю. Биков // Інформаційні технології в освіті. - Херсон, 2011. № $10 .-$ C. $8-23$.

2. Вакалюк Т. А. Теоретико-методичні засади проектування i використання хмаро оріснтованого навчального середовища у підготовці бакалаврів інформатики: дис. ... доктора пед. наук: 13.00.10 «Інформаційно-комунікаційні технології в освіті» / Т. А. Вакалюк. - К., 2019. - 614 с.

3. Маркова О. М. Хмарні технології навчання: витоки / О. М. Маркова, С. О. Семеріков, А. М. Стрюк // Інформаційні технології і засоби навчання. - 2015. № 2 (46). - C. 29-44. URL: http://journal.iitta.gov.ua (дата звернення: 01.09.2019).

4. Морзе Н. В. Педагогічні аспекти використання хмарних обчислень / Н. В. Морзе, О. Г. Кузьмінська // Інформаційні технології в освіті. - 2011. - № 9. - С. 20-29.

5. Попель М. В. Хмарний сервіс SageMathCloud як засіб формування професійних компетентностей вчителя математики / М. В. Попель Dissertation, Institute of Information Technologies and Learning Tools of NAES of Ukraine. - 2017. - 311 p.

6. Словак К. І. Методика використання мобільних математичних середовищ у процесі навчання вищої математики студентів економічних спеціальностей: ареф. дис. на здобуття наук. ступеня канд. пед. наук : спец. 13.00.10 «ІКТ в освіті» / К. І. Словак. - К., 2011. $-20 \mathrm{c}$.

7. Соловйов А. В. Використання хмарних сервісів Google Drive та Telegram при підготовці майбутніх фахівців засобами наскрізного моделювання / А. В. Соловйов // Фізико-математична освіта. -2018. - № 3 (17). - С. 89-93.

8. Спірін О. М. Досвід підготовки наукових кадрів 3 інформаційно-комунікаційних технологій в освіті (до 15-річчя Інституту інформаційних технологій і засобів навчання НАПН України) / О. М. Спірін, А. В. Яцишин // Комп’ютер у школі та сім’ї. - 2014. № 2. - C. 3-8.

9. Спірін О. М. Сучасні вимоги і зміст підготовки наукових кадрів вищої кваліфікації 3 iнформаційно-комунікаційних технологій в освіті / О. М. Спірін, Ю. Г. Носенко, А. В. Яцишин // Інформаційні технології і засоби навчання. -2016. - № 6 (56). C. 219-239. URL: http://journal.iitta.gov.ua (дата звернення: 07.09.2019).

10. Хмарні сервіси і технології у науковій і педагогічній діяльності : методичні рекомендації / за ред. М. П. Шишкіної. - К., 2016. - 73 с.

11. Шишкіна М. П. Теоретико-методичні засади формування і розвитку хмаро орієнтованого освітньо-наукового середовища вищого навчального закладу: дис. ... доктора пед. наук : 13.00.10 «Інформаційно-комунікаційні технології в освіті» / М. П. Шишкіна. - К., 2016. - 441 с.

12. Яцишин А. В. Використання цифрових відкритих систем у підготовці аспірантів і докторантів / А. В. Яцишин // Освіта та розвиток обдарованої особистості. - 2018. - № 1 (68). - С. 18-23.

13. Guolei Zhang, Jia Li, Li Hao. Cloud Computing and Its Application in Big Data Processing of Distance Higher Education. International Journal of Emerging Technologies in Learning. 2015. Vol. 10, № 8. P. 55-58. URL: http://online-journals.org/index.php/i-jet/article/ view/5280/3701 (дата звернення: 10.09.2019).

14. Iatsyshyn Anna, Kovach Valeriia, Romanenko Yevhen, Iatsyshyn Andrii. Cloud services application ways for preparation of future $\mathrm{PhD}$. Cloud Technologies in Education. Proceedings of the 6 th Workshop CTE 2018, 197-216. URL: http://ceur-ws.org/Vol-2433/paper12.pdf (дата звернення: 03.10.2019).

15.ISO/IEC 17788:2014(E) Information technologyCloud computing - Overview and vocabulary. - First edition 2014-10-15. - 2014. - $16 \mathrm{p}$.

16. Mell P., Grance T. The NIST Definition of Cloud Computing. Recommendations of the National Institute of Standards and Technology - NIST Special Publication 800-145. NIST, Gaithersburg, MD 20899-8930, September, 2011.

17. Singh U., Baheti P.K. Role and Service of Cloud Computing for Higher Education System. International Research Journal of Engineering and Technology, 4 (11), 708-711. URL : https://www.irjet.net/archives/ V4/111/IRJET-V4I11125.pdf. (2017) (дата звернення: 07.09.2019).

Дата надходження до редакиї: 16.09.2019 р. 